\title{
An investigation on the relationship between Service Quality and Customer Loyalty: A mediating role of Customer Satisfaction
}

\author{
Vithya Leninkumar \\ Lecturer, Trincomalee Campus, Eastern University, Sri Lanka
}

\begin{abstract}
Post war developments in Northern Province of Sri Lanka paved a way for hypercompetition in the market place among the already existing and the new banks where the former focuses on retaining the existing customers and the latter on attracting new customers. Such an intense competition emphasizes the need for identification of determinants of customer loyalty. Thus, the current study attempts to fill the empirical gap that exists especially in the Sri Lankan context. The study was conducted in a Commercial Bank setting and the hypotheses were developed in order to find out the relationship between the constructs. The population consisted of customers of Commercial Banks in the Northern Province of Sri Lanka and the sample of 300 respondents were selected. The data were analyzed using SPSS version 21.0 and SmartPls version 3.0. The findings revealed a positive, significant direct relationship between the service quality and customer satisfaction; customer satisfaction and customer loyalty and service quality and customer loyalty. Further, mediating effect of customer satisfaction between service quality and customer loyalty was proved. The paper discusses both Theoretical and practical implications.
\end{abstract}

Keywords: Customer Loyalty, Service quality, Customer satisfaction, Service quality dimensions, Commercial banks.

\section{INTRODUCTION}

Current market environment is highly competitive than ever before (Sivadas and BakerPrewitt, 2000) where marketers try their best to capture a big market share. As stated by Arasli, Katircioglu and Mahtap-Smadi (2005) there is a growing importance of services in the world economy. Marketing of services indicates an intense competition (Zeithaml, Bitner, Gremler and Pandit, 2011) which is because of its' special characteristics such as intangibility, heterogeneity, inseparability and perishability. Moreover, the arrival of new firms in the market with almost similar products or services led to high competition and made the customers avail with number of options or choices which in turn equipped them with high bargaining power. The massive use of marketing communication tools enhanced the customer awareness and differentiation of brands (Andreassen and Lindestad, 1998). To compete in such congested and interactive marketplace, firms are forced to look beyond the traditional marketing strategies, which are no longer enough to be implemented for achieving competitive advantage. Hence, the firms have to find out different strategies for their survival in the market and to maintain their current position in an ever increasing competitive market place (Kandampully, 1998).

Service organizations are seeking ways to forge and to maintain an on-going relationship with their customers in order to protect their long term interest (Kandampully, 1998). Just attracting new customers in the market place is not enough rather organizations need to give more importance to the customer retention (Santouridis and Trivellas, 2010). Retention of existing customer is cheaper than attracting new customers. Further, loyal customers are more profitable to the firm and are sympathising with poor service and displaying poor sensitivity to price (Yang and Peterson, 2004). This reveals the need for building customer loyalty through 
long-term customer relationships. As customer loyalty is the final goal of relationship marketing, it is concerned about building customer loyalty by providing value to all the parties involved in the relational exchanges (Peng and Wang, 2006).

There are several constructs identified by the past researchers as the determinants of customer loyalty such as service quality (Tarus and Rabach, 2013; Malik, Naeem and Arif, 2011; Puja and Yukti, 2011; Gurbuz, 2008; Ehigie, 2006; Bloemer, Ruyter and Wetzels, 1999; Zeithaml et al. 1996) customer satisfaction (Keisidou et al. 2013; Santouridis and Trivellas, 2010; Ehigie, 2006; Yang and Peterson, 2004), perceived service value (Tarus and Rabach, 2013; Yang and Peterson, 2004), customer trust (Roostika, 2011; Filip and Anghel, 2009), commitment (Ou, Shih, Chen, and Wang, 2011; Filip and Anghel, 2009), and perception of image (Keisidou et al. 2013; Akhter et al. 2011; Andreassen and Lindestad, 1998; Bloemer et al.1998). In addition, switching cost serves as a moderator (Rahman and Kamarulzaman, 2012; Filip and Anghel, 2009; Yang and Peterson, 2004) in the service quality and customer loyalty relationship. Ruyter, Wetzels and Bloemer, (1998) documented that the determinants of service loyalty were varied per industry.

Previous studies have focused different industries namely, telecommunication (Tarus and Rabach, 2013; Santouridis and Trivellas, 2010), hotel industry (Poku, Zakari and Soali, 2013; Rousan, Razmi and Mohamed, 2010; Lee, Barker and Kadampully, 2003), casinos (Pretice, 2013), tourism (Andreassen and Lindestad, 1998) entertainment, fast food industry, health care, Supermarkets (Bloemer et al., 1999; Rutyer et al., 1998), restaurants (Puja and Yukti, 2011), department stores (Ou et al. 2011; Sivadas and Baker-Prewitt, 2000), e-mail service providers (Ranganathan, Madupu, Sen and Brooks, 2013), call centres (Dean, 2002), library service (Kiran and Diljit, 2011) and banking industry (Caruana, 2002; Ganguli and Roy, 2011; Bloemer, Ruyter and Peeters, 1998; Hallowell, 1996; Olorunniwo and Hsu, 2006; Ehigie, 2006) Service quality is one of the important antecedents of customer loyalty which has a direct and indirect impact on the later (Bloemer et al., 1998). Therefore, this is an attractive area for researchers over the last decade in banking sector (Bloemer et al. 1998; Ruyter and Peeters, 1998; Caruana, 2002; Dhandabani, 2010; Sureshchandar et al. 2002; Mosahab et al. 2010). To achieve customer loyalty, management should meet the diverse customer demands. According to Parasuraman et al., (1985) Service quality is positively related to loyalty because improved service quality could enhance loyalty where some other researchers (Hassan et al. 2013; Mosahab et al. 2010; Olorunniwo and Hsu, 2006; Caruana, 2002) revealed an indirect impact through customer satisfaction. Dick and Basu (1994) viewed perceived service quality as a key determinant of satisfaction with potential consequences for repeat patronage. Besides, Santouridis and Trivellas (2010) states that service quality and customer satisfaction are the crucial factors that lead to customer loyalty. Dick and Basu (1994) viewed perceived service quality as a key determinant of satisfaction with potential consequences for repeat patronage. According to Tam (2012), satisfied customers are more likely to make more repeat purchases and to share their positive experiences with others. Further, satisfied customers are likely to concentrate their business with the same provider and recommend the provider to others. Therefore, the current study focuses on the constructs of service quality, customer satisfaction and customer loyalty.

\section{PROBLEM STATEMENT AND JUSTIFICATION}

The current study intended to investigate whether there is a significant relationship between service quality, customer satisfaction and customer loyalty in the commercial banks of the Northern Province of Sri Lanka. While reviewing the literature, it was found that there were researches on investigating the impact of service quality and customer satisfaction on customer loyalty in different industries across the globe. There were some researches initiated 
in Asia (Hassan, Mallik Imran, Hasnain and Abbas 2013; Hafeez and Muhammad, 2012; Annamalah, Munusamy, Chelliah, Sulaiman and Pandian, 2011; Siddiqi, 2011; Kheng, Mahamad, Ramayah and Mosahab, 2010; Dhandabani, 2010). But it was felt that, there is not that much of importance given to researches on customer loyalty in the Sri Lankan context where the constructs of service quality and customer satisfaction were studied intensively (Silva and Abeysekara, 2012; Sivesan, 2012; Kumaradeepan, 2012). In Sri Lanka, the construct of customer loyalty has been studied only with limited constructs and there were very few studies found in testing the relationship between the constructs of service quality, customer satisfaction and customer loyalty, there is a need still to fill the empirical gap. Moreover, some studies proved that the relationship between service quality and customer loyalty has been strengthened by customer satisfaction (Caruana, 2002; Tarus and Rabach, 2013). Hence, this research focuses on the constructs of service quality, customer satisfaction and customer loyalty and it is an attempt to fill the empirical gap in the Sri Lankan context, especially focusing on the Northern Province.

The Northern Province of Sri Lanka was directly affected by the war over three decades and has started to rebuild its economy with the end of the war in 2009. The post war situation created the opportunity for the extension of existing bank branches as well as the arrival of new private banks which in turn increased the competition among commercial banks in the Northern Province. Further, products offered to the customers of a bank are more or less standardized in nature (Ganguli and Roy, 2011) and the use of multiple banks and customer switching is a common feature among commercial banking customers, being the consequence of stiff competition (Silva, 2009). This competition forces the banks to realize the need for retaining the existing customers and make them loyal to the bank in any possible way. These are the reasons for directing special attention to the commercial banks of Northern Province of Sri Lanka in this study.

\section{RESEARCH OBJECTIVES}

1. To investigate the relationship between service quality and customer satisfaction.

2. To investigate the relationship between customer satisfaction and customer loyalty.

3. To investigate the relationship between service quality and customer loyalty.

4. To investigate the relationship between service quality and customer loyalty with the mediation of customer satisfaction.

\section{Service Quality}

\section{LITERATURE REVIEW}

During the past few decades service quality has drawn much attention from practitioners and researchers due to its strong impact on cost, customer satisfaction, retention, positive word of mouth, customer loyalty, business performance and profitability. Even though, defining service quality is not very easy, Gronroos (1984) defined service quality as the outcome of the evaluation process where the customer compares his expectation with the service he perceives during the service encounter. Similarly, Parasuraman et al. (1988) delineated service quality as the consumer's overall evaluation of a specific service firm that results from comparing that firm's performance with the customers' general expectations of how firms in that industry should perform.

Based on the literature and the definitions given by the scholars, in the current study, service quality in respect of commercial banks defined as "the customer's overall evaluation of the bank's performance with his/ her expectation". 


\section{Customer Satisfaction}

Customer satisfaction is a well-established concept in several sciences especially in marketing. According to Tam (2012), Customer satisfaction is a cornerstone of all marketing activies. In the academic literature, customer satisfaction is postulated as a function of discrepancy between consumer's prior expectations and his or her perception regarding the purchase (Oliver, 1980, 1993; Yi, 1990). According to Oliver (1997) satisfaction is a judgment that a product or service feature, or the product or service itself, provided (or is providing) a pleasurable level of consumption-related fulfilment, including levels of under- or overfulfilment. Kotler (2003) defined satisfaction as a person's feeling of pleasure or disappointment resulting from comparing a product's perceived performance in relation to his or her expectations (Kotler, 2003, p.36). Therefore satisfaction is closely related to consumer expectation. Moreover, Giese and Cote (2000) defined customer satisfaction as a summary of affective responses of varying intensity and occurs at a particular time and is of limited duration and pertains to a particular focus as product choice, purchase or consumption. Jamal and Naser (2003) also defined customer satisfaction as a composite of overall attitudes that customers have towards the bank.

Combining the different definitions provided by the different scholars, the current study defines customer satisfaction as "customers' feelings of pleasure or disappointment resulting from the evaluation of their prior expectation and the perceived performance".

\section{Customer Loyalty}

Nowadays, research on customer loyalty has received considerable attention in the literature even though, defining and measuring loyalty has proved to be extremely difficult (Yang and Peterson, 2004). The benefits of customer loyalty accentuated the requirement of a thorough understanding in this area. Gremler and Brown (1996) defined service loyalty as the degree to which a customer exhibits repeat purchasing behaviour from a service provider, possesses a positive attitudinal disposition toward the provider, and considers using only this provider when a need for this service arises. They emphasized that a loyal customer uses the service regularly, thinks highly about the organization and never considers about using another service provider. Based on the definition of Jacoby and Chestnut, Bloemer et el. (1998) defined customer (bank) loyalty as the biased (non-random) behavioural response (revisit), expressed over time, by some decision making unit with respect to one bank out of a set of banks, which is a function of psychological (decision making and evaluative) processes resulting in brand commitment. Likewise, Ou et al. (2011) defined loyalty as a held commitment to re-buy or repatronize a preferred product consistently in the future.

By looking at the definition given by scholars, and combining those ideas, customer loyalty could be defined as "a deeply held commitment to rebuy the service from the same provider consistently in the future and possessing a positive attitudinal disposition toward the provider".

\section{CONCEPTUAL MODEL}

A formal way of synthesizing and presenting literature is through the use of a conceptual model. Since this study mainly focuses on examining the relationship between service quality, customer satisfaction and customer loyalty in commercial banks, the conceptual model is developed in such a way as to study the relationship among those constructs. 


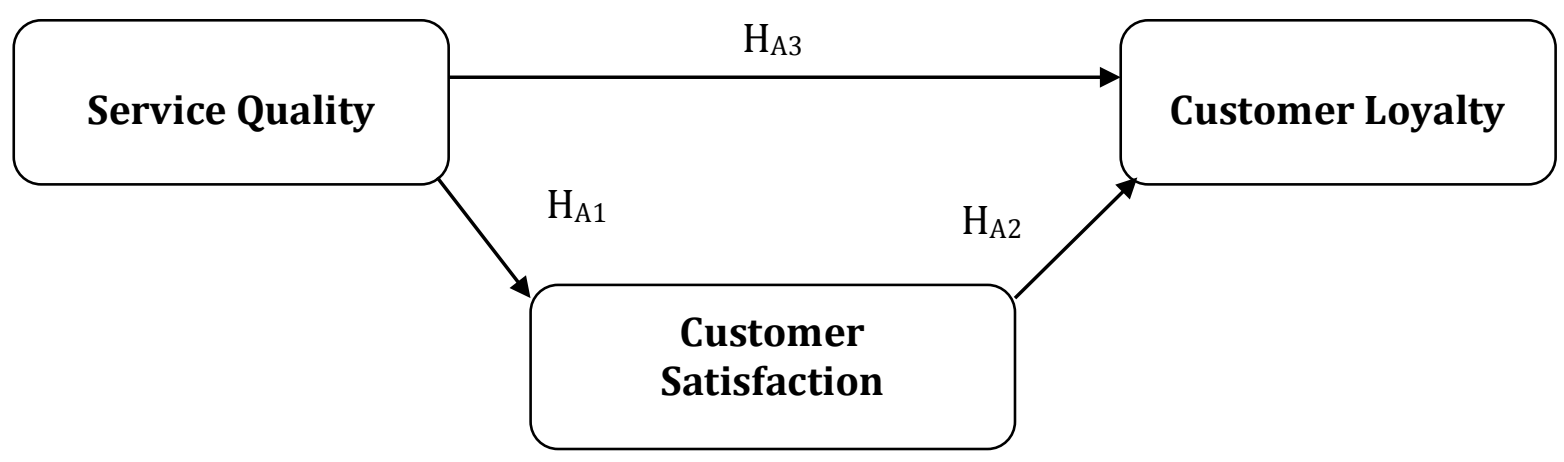

Figure 1: Conceptual model

\section{HYPOTHESES FOR THE STUDY ANALYSIS}

Four hypotheses $\left(\mathrm{H}_{\mathrm{A} 1}, \mathrm{H}_{\mathrm{A} 2}, \mathrm{H}_{\mathrm{A} 3}\right.$ and $\left.\mathrm{H}_{\mathrm{A} 4}\right)$ are formulated based on the conceptual model to achieve the research objectives of this study.

\section{Service Quality and Customer Satisfaction}

Service quality has been found as an important input to or the antecedent of customer satisfaction (Kiran and Dilgit, 2011; Santouridis and Trivellas, 2010; Jamal and Naser, 2003; Caruana, 2002; Yavas et al., 1997). Favourable service quality sentiments were expected to result in higher levels of customer satisfaction and commitment (Yavas et al., 1997). Continuous improvement of service quality and customer satisfaction is required due to the strong correlation between the two constructs and further, superior service quality and high levels of customer satisfaction are the important goals to enhance the business performance of banks (Sureshchandar et al., 2002).

A study conducted by Arasli et al. (2005) spotted that all the service quality dimensions were statistically significant for overall satisfaction in Northern Cyprus and except for tangibles the other dimensions were statistically significant for banks in Southern Cyprus. According to Yavas et al. (1997) service quality dimensions namely responsiveness, empathy and tangibles were identified as significant predictors of Turkish customer satisfaction. For responsiveness, they emphasized the need for training programmes to be provided by the banks to their employees, specifically on listening skills. Further, in the case of empathy the banks were expected to give individual attention to customers and understand their specific needs. They suggested the banks use empathy as a weapon to compete in the battle field in order to prove their quality service which can bring a tremendous opportunity to the bank. Besides, in Malaysian banks, other than responsiveness and empathy, assurance was also found to have a significant positive relationship with customer satisfaction (Kheng et al., 2012). These findings have been further confirmed by Keisidou et al. (2012).They found that not the functional quality but the relational quality had a positive impact on customer satisfaction. They argued that, since all the banks provide the same level of functional quality, customers mainly focus on the relational quality of the bank where the intimacy received by the customers from the bank and its employees is mostly concentrated.

In addition, Yavas et al. (1997) emphasized the need for a pleasant banking environment and they suggested the adoption of a no smoking policy in a country dominated by smokers and where there is no such existing policy. The prominence of tangibles was further supported by Keisidou et al. (2012). They stated that the impact of tangibles on affective responses of customers such as the sense of pleasure, relaxation and the feeling of excitement led to a positive effect on customer satisfaction. In technology based banking, customer satisfaction is 
highly affected by the customer service. In other words, proper customer service shapes consumer behaviour patterns (Ganguli and Roy, 2011). Moreover the importance of the ease of use of technology and its reliability was also found to be important.

Thus, based on the above justification the following hypothesis is proposed:

$\mathbf{H}_{\mathrm{A1}}$ : There is a direct and positive relationship between service quality and customer satisfaction

\section{Customer Satisfaction and Customer Loyalty}

The more the customer is satisfied with the services of the bank the more likely the customer would be loyal and it is considered as a leading factor in determining loyalty (Ehigie, 2006). In addition, customer satisfaction was found to be more important than service quality perception in gaining customer loyalty (Ehigie, 2006). Similarly, Keisidou et al. (2012) also found that customer satisfaction has a strong effect on customer loyalty. Since customer satisfaction is the strongest predictor of customer loyalty, the managers should give more priority to customer satisfaction. If a bank repeatedly satisfies the customer, that customer will continue to do transactions with the same provider (Keisidou et al., 2012) and recommend the bank to others (Dhandabani, 2010). Further, Bloemer et al. (1998) found a direct relationship between customer satisfaction and customer loyalty in the banking sector. Tam (2012) stated that, higher satisfaction would enhance loyal behaviour. The service provider must understand the important aspects of service that contribute more to customer satisfaction to effectively influence loyalty. Arasli et al. (2005) found a positive relationship between customer satisfaction and on customer's word of mouth which revealed that if a customer is satisfied with the service provided by the bank he/she will engage in spreading positive word of mouth to others about the bank.

Moreover, a significant positive relationship between customer satisfaction and customer loyalty has been proved in the technology based banking services such as internet banking, ATM banking, mobile banking etc. (Ganguli and Roy, 2011). As there is high risk in the use of technology in business transactions, customer satisfaction is identified as an important factor. If the customer is satisfied with the previous encounter with the technology channel, he/she will reuse the same channel for future transactions.

Based on the above justification, the following hypothesis is proposed:

$\mathbf{H}_{\mathrm{A} 2}$ : There is a direct and positive relationship between customer satisfaction and customer loyalty

\section{Service Quality and Customer Loyalty}

Service quality is the outcome of the evaluation process, where the customer compares his expectation with the service he perceives while he actually consumed the service (Gronroos, 1984) and the quality of the service provider plays a pivotal role in services which require a high degree of contact with the service provider (Tam, 2012). Service quality is a major predictor of both customer satisfaction and loyalty (Santouridis and Trivellas, 2010). Loyalty is the extent to which a customer regards himself or herself as loyal, the customer's willingness to recommend the bank to others, and his or her intention to continue to use the bank in the future (Komunda et al., 2012). The initial choice and the continued patronage by customers are strongly influenced by the quality of service rendered (Tarus and Rabach, 2013). According to Gurbuz (2008) customers who favourably perceive the service quality will tend to develop loyalty to the firm and its brand as a consequence. Different dimensions of service quality had differing impacts on the loyalty of customers and their future patronage (Prentice, 2013). 
Service quality has both direct and indirect effects on bank loyalty (Bloemer et al, 1998). In the banking service (in Netherland) reliability was found to be the most important factor that influences customer loyalty. Further Bloemer et al. (1998) indicated the necessity of trustworthy impression of employees on the customers in general service encounters as well as in complaint handling. In other words, the need for investment in monitoring the employees was emphasized. Similarly Kheng et al. (2012) also found a positive relationship between reliability, empathy, assurance and customer loyalty in Malaysian banks. They argued that, in the case of empathy, the friendship between the customers and service employees contribute to the development of customer loyalty. In the Pakistan banking environment Malik et al. (2011) found a significant impact of service quality dimensions; tangibles, empathy and assurance on customer loyalty where tangibles posted more impact than the other two. In contrast to this, another study in Malaysia indicated that tangibles had no significant impact on customer loyalty in banks due to the availability of self-service terminals (Kheng et al., 2012).

Moreover, a positive relationship has been observed between service quality and preference loyalty and price indifference loyalty where the influence of service quality on preference loyalty varied per industry (Ruyter et al., 1998). Ruyter et al. (1998) further stated that favourable disposition towards the service provider and the increased commitment to repatronage can be achieved through higher service quality and consumers are less sensitive to price increases in services at higher service quality levels. As the dissatisfaction response is related to an incident or specific service attribute, it was found to be insignificant. In contrast, Yavas et al. (1997) revealed that service quality negatively related to the complaining behaviour of customers where empathy only had a significant relationship. Good service quality results in lower likelihoods of complaint and the complaints help the banks to improve the performance of the employees in empathy. Further, Zeithaml (1996) also supporting this finding, stated that customers who experience no service problems have the strongest level of loyalty intentions and the weakest switch and external response intentions.

Accordingly the following hypothesis is proposed:

$\mathbf{H}_{\mathrm{A} 3}$ : There is a direct and positive relationship between service quality and customer loyalty

Through the mediation of customer satisfaction, an indirect effect of service quality on customer loyalty was observed in several studies (Caruana, 2002). As some of the researchers found, both direct and indirect effects between the constructs (Mosahab et al., 2010; Bloemer et al, 1998), some studies only found indirect effects with the mediation of customer satisfaction (Annamalah et al., 2011; Kiran and Dilgit, 2011; Olorunniwo and Hsu, 2006; Caruana, 2002). According to Annamalah et al. (2011), banks can achieve customer loyalty through highly satisfying the customers where satisfaction is determined by the customers' perception of service quality. Findings of Hassan et al. (2013) reflected a full mediation of customer satisfaction between reliability assurance and customer loyalty while empathy and customer loyalty were partially mediated by customer satisfaction. It was reported that, with the mediation of satisfaction, the impact of service quality on behavioural intention had become stronger (Olorunniwo and Hsu, 2006).

Thus, based on the above justification the following hypothesis is proposed:

$\mathbf{H}_{\mathrm{A} 4}$ : There is an indirect and positive relationship between service quality and customer loyalty through customer satisfaction.

\section{METHODS}

This research has adopted the deductive approach of testing the theory and the purpose of the study is to test the hypotheses in order to achieve the research objectives. The unit of analysis 
of this study is all individual bank customers of four leading commercial banks in the Northern Province of Sri Lanka who had dealing with the bank for more than five years and who were aged above 18 years. The data were collected from 300 respondents using the convenience sampling method. Every respondent was asked to choose a bank as their main bank among those they might have transactions and where they maintained at least one active account for more than five years.

\section{Construction of instrument}

The current study has also adopted the model of Parasuraman et al. (1988), including a 22item Likert-type scale in order to measure the service quality. Further this study has adopted the argument of Caruana (2002) that service quality can be measured only with customer perception where customers give their response using the comparison. This also can avoid the boredom in answering a lengthy questionnaire. The construct of customer satisfaction measured through a 5-items scale measurement adopted from Gremler and Gwinner (2000). A five-item instrument adopted from Zeithaml (1996) used to measure customer loyalty which was used and validated by Tam (2012). The measures were assessed on a five-point scale and the pilot study results proved an acceptable level Cronbach's Alpha value.

Table 1: Operaltionalization

\begin{tabular}{|c|c|c|c|}
\hline Concepts & Dimensions & Items & $\begin{array}{l}\text { Previous } \\
\text { studies }\end{array}$ \\
\hline \multirow{17}{*}{$\begin{array}{l}\text { Service } \\
\text { Quality }\end{array}$} & \multirow{4}{*}{ Tangibles } & 1. My bank has modern looking equipment & \multirow{17}{*}{$\begin{array}{l}\text { Parasuraman } \\
\text { et al. (1985) } \\
\text { Caruana } \\
(2002)\end{array}$} \\
\hline & & $\begin{array}{l}\text { 2. My bank's physical facilities are visually } \\
\text { appealing. }\end{array}$ & \\
\hline & & $\begin{array}{l}\text { 3. My bank employees are well dressed and } \\
\text { appear neat. }\end{array}$ & \\
\hline & & $\begin{array}{l}\text { 4. Materials associated with the service } \\
\text { (such as pamphlets or statements) are } \\
\text { visually appealing at bank. }\end{array}$ & \\
\hline & \multirow{5}{*}{ Reliability } & $\begin{array}{l}\text { 5. When my bank promises to do something } \\
\text { by a certain time, it does so. }\end{array}$ & \\
\hline & & $\begin{array}{l}\text { 6. When I have a problem, my bank shows } \\
\text { sincere interest in solving it. }\end{array}$ & \\
\hline & & $\begin{array}{l}\text { 7. My bank performs the service right the } \\
\text { first time }\end{array}$ & \\
\hline & & $\begin{array}{l}\text { 8. My bank provides its services at the time } \\
\text { it promises to do so. }\end{array}$ & \\
\hline & & 9. My bank insists on error-free records & \\
\hline & \multirow{4}{*}{$\begin{array}{l}\text { Responsiv } \\
\text { eness }\end{array}$} & $\begin{array}{l}\text { 10. My bank keeps customers informed about } \\
\text { when services will be performed. }\end{array}$ & \\
\hline & & $\begin{array}{l}\text { 11. Employees in my bank give me prompt } \\
\text { service }\end{array}$ & \\
\hline & & $\begin{array}{l}\text { 12. Employees in my bank are always willing } \\
\text { to help me }\end{array}$ & \\
\hline & & $\begin{array}{l}\text { 13. Employees in my bank are never too busy } \\
\text { to respond to my request. }\end{array}$ & \\
\hline & \multirow{4}{*}{ Assurance } & $\begin{array}{l}\text { 14. The behaviour of employees in my bank } \\
\text { instils confidence in me }\end{array}$ & \\
\hline & & 15. I feel safe in my transactions with my bank & \\
\hline & & $\begin{array}{l}\text { 16. Employees in my bank are consistently } \\
\text { courteous to me }\end{array}$ & \\
\hline & & $\begin{array}{l}\text { 17. Employees in my bank have knowledge to } \\
\text { answer my questions }\end{array}$ & \\
\hline
\end{tabular}




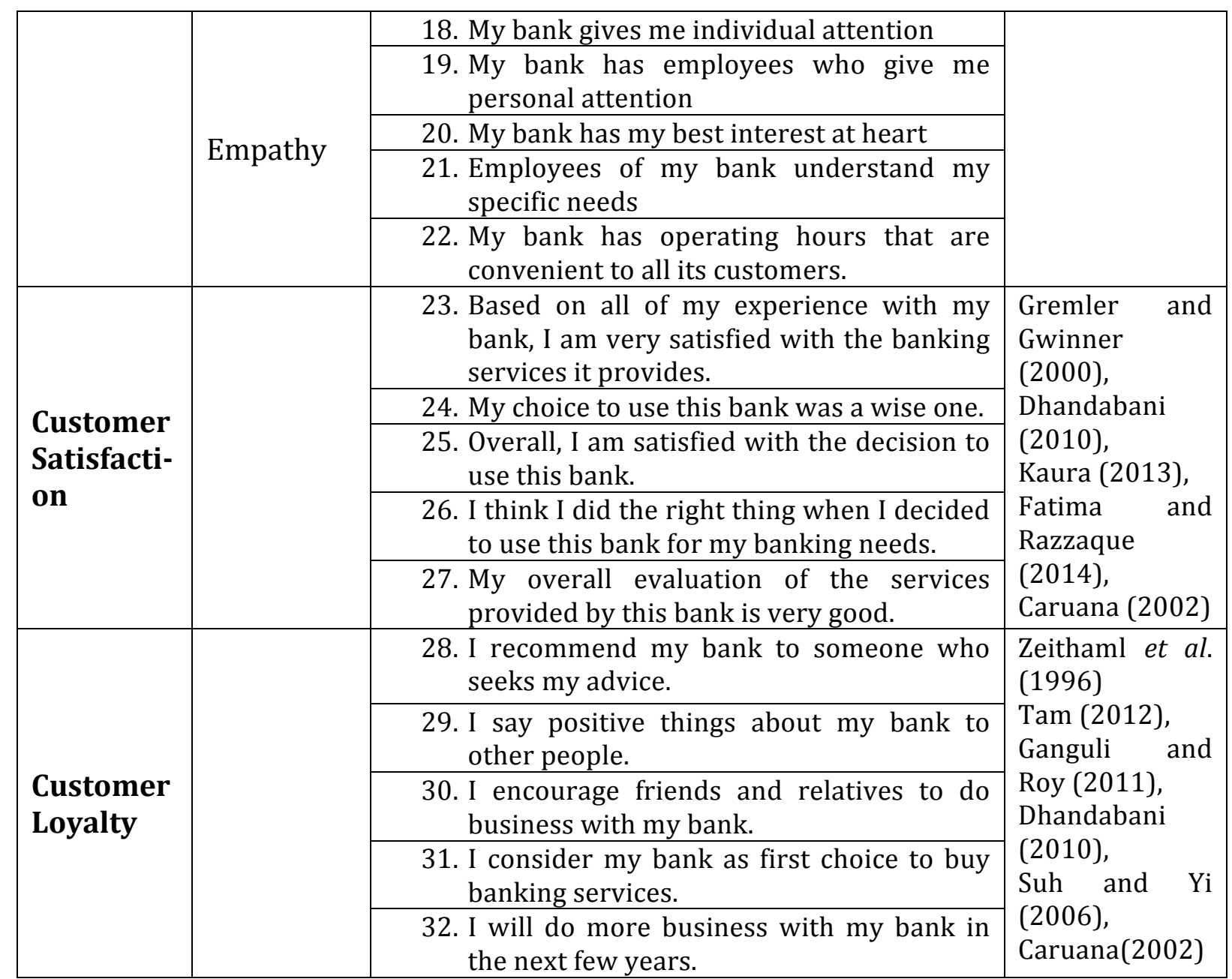

(Source: Developed for study purpose)

\section{METHODS OF DATA ANALYSIS}

The data was analyzed using the Statistical Package for Social Sciences (SPSS) Version 21.0 in order to describe the demographic information and characteristics of research information. SmartPLS version 3.0 was used in the test of hypotheses.

\section{ANALYSIS}

Sample characteristics and banking behaviour

The following table presents the demographic factors of the respondents. The analysis of the respondent demographics revealed that the majority of the respondents were female and majority of the respondents' educational qualification was either G.C.E (A/L) or the degree. Further, the majority of the customers were aged between 28 - 47 and the majority had a monthly income between Rs.25,001 - 50,000. Further, the majority of the respondents have their relationship with the bank for more than 13 years. 
Table 2: Demographics of the respondents

\begin{tabular}{|c|c|c|}
\hline Characteristics & Categories & Percentage \\
\hline \multirow[t]{2}{*}{ Gender } & Male & $44 \%$ \\
\hline & Female & $56 \%$ \\
\hline \multirow[t]{5}{*}{ Age } & $18-27$ & $19.5 \%$ \\
\hline & $28-37$ & $30.2 \%$ \\
\hline & $38-47$ & $28.3 \%$ \\
\hline & $48-57$ & $19.1 \%$ \\
\hline & Above 57 & $2.9 \%$ \\
\hline \multirow[t]{5}{*}{ Educational Qualification } & G.C.E $(\mathrm{O} / \mathrm{L})$ and below & $11.2 \%$ \\
\hline & G.C.E (A/L) & $34.9 \%$ \\
\hline & Graduate & $35.3 \%$ \\
\hline & Postgraduate & $5.4 \%$ \\
\hline & Professional & $13.3 \%$ \\
\hline \multirow[t]{6}{*}{ Monthly Income } & Below Rs. 10,000 & $8 \%$ \\
\hline & Rs. $10,001-25,000$ & $26.5 \%$ \\
\hline & Rs. $25,001-50,000$ & $45.1 \%$ \\
\hline & Rs. $50,001-75,000$ & $11.7 \%$ \\
\hline & Rs. $75,001-100,000$ & $5.9 \%$ \\
\hline & Above Rs. 100,000 & $2.8 \%$ \\
\hline \multirow{4}{*}{$\begin{array}{l}\text { Number of years of cooperation } \\
\text { with the bank }\end{array}$} & 5-7 years & $19.9 \%$ \\
\hline & $8-10$ years & $25.3 \%$ \\
\hline & $11-13$ years & $19.1 \%$ \\
\hline & More than 13 years & $35.7 \%$ \\
\hline
\end{tabular}

(Source: Survey data)

\section{Confirmatory factor analysis using SPSS}

Pre analysis testing for suitability of the entire sample for factor analysis was computed using the Kaiser-Meyer-Olkin (KMO) measure of sampling adequacy and Bartlett tests of sphericity. The KMO measure of sampling adequacy was $0.870,0.859$ and 0.824 for service quality, customer satisfaction and customer loyalty respectively and the Bartlett tests of sphericity was significant at 0.000 for all three constructs (see table 3). These results indicated that the sample was suitable for factor analytic procedures.

Table 3: Eigen values, Total Variance Explained, KMO measure of sampling adequacy and Cronbach's alpha values

\begin{tabular}{|l|l|c|c|l|c|}
\hline & $\begin{array}{l}\text { Eigen } \\
\text { value }\end{array}$ & $\begin{array}{l}\% \\
\text { variance }\end{array}$ & $\begin{array}{l}\text { KMO Sampling } \\
\text { Adequacy }\end{array}$ & $\begin{array}{l}\text { Bartlett's } \\
\text { test } \\
\text { Significance }\end{array}$ & $\begin{array}{l}\text { Cronbach's } \\
\text { alpha }\end{array}$ \\
\hline Service Quality & 3.383 & 67.65 & 0.870 & 0.000 & 0.877 \\
\hline $\begin{array}{l}\text { Customer } \\
\text { Satisfaction }\end{array}$ & 3.497 & 69.95 & 0.859 & 0.000 & 0.891 \\
\hline Customer Loyalty & 3.032 & 60.64 & 0.824 & 0.000 & 0.796 \\
\hline
\end{tabular}

(Source: Survey data)

Consistent with the findings of Parasuraman et al. (1988), the current study also identified five factors of service quality which hold Eigen values greater than one. These five dimensions of service quality accounted for nearly $68 \%$ of the variance (see table 3 ). The items of customer satisfaction also loaded with its' predestined factor and the Eigen value greater than one where these items explained nearly $70 \%$ of the variance (see table 3 ). Items of customer loyalty 
explained almost $61 \%$ of the variance and the Eigen value greater than (see table 3 ). In this current study, almost all items of service quality, customer satisfaction and customer loyalty had loadings greater than the widely accepted thumb rule of 0.5 (Hair et al., 1998) except Loy1. However, the loading of Loy 1 is 0.491 which is also closer to 0.5 .

As, the Eigen values of all constructs were greater than one and the loadings of almost all individual items were above 0.5 , the unidimensionality of the factors was ensured.

\section{Structural equation modelling}

The examination of the conceptual framework was conducted with the use of the structural equation modelling technique (SmartPls Version 3.0) as it has the ability to examine a number of dependent and independent variables simultaneously where one or more constructs are both dependent and independent (Hair et al., 1998). Moreover, it helps to calculate the direct and indirect effects between constructs.

\section{Measurement model analysis}

Measurement model specifies the relationship between the latent variables and their observed indicators (Wong, 2013). Before the testing of hypotheses, the measurement model should be tested as basis. The strength of the measurement model is ensured by the examination of factor loading and internal consistency reliability. Outer loadings of all indicators of all constructs ranged between 0.491 and 0.880 and were statistically significant. Thus, the indicator reliability was established. Further, the composite reliability of the constructs service quality, customer satisfaction and customer loyalty were correspondingly $0.912,0.921$, and 0.881 (see table 4). As all the composite reliability values were above the widely recognised rule of thumb of 0.7 , the internal consistency reliability was proved.

The measurement models' validity assessment focuses on convergent validity and discriminant validity. The convergent validity is attested based on the value of Average Variance Extracted (AVE). Table 4 presents the value of each construct; service quality, customer satisfaction and customer loyalty as $0.676,0.699$ and 0.605 respectively. Since all the values were above the threshold value of 0.5 , the convergent validity was confirmed. 
Table 4: Summary of results of measurement model

\begin{tabular}{|c|c|c|c|c|c|}
\hline Construct & Indicators & Loadings & $\begin{array}{l}\text { Composite } \\
\text { reliability }\end{array}$ & $\begin{array}{l}\text { Cronbach's } \\
\text { alpha }\end{array}$ & $\begin{array}{l}\text { Average } \\
\text { Variance } \\
\text { Extracted } \\
\text { (AVE) }\end{array}$ \\
\hline \multirow{5}{*}{$\begin{array}{l}\text { Service } \\
\text { Quality }\end{array}$} & Tangibles & 0.683 & \multirow{5}{*}{0.912} & \multirow{5}{*}{0.878} & \multirow{5}{*}{0.676} \\
\hline & Reliability & 0.868 & & & \\
\hline & Responsiveness & 0.880 & & & \\
\hline & Assurance & 0.876 & & & \\
\hline & Empathy & 0.788 & & & \\
\hline \multirow{5}{*}{$\begin{array}{l}\text { Customer } \\
\text { satisfaction }\end{array}$} & SAT 1 & 0.792 & \multirow{5}{*}{0.921} & \multirow{5}{*}{0.892} & \multirow{5}{*}{0.699} \\
\hline & SAT 2 & 0.832 & & & \\
\hline & SAT 3 & 0.857 & & & \\
\hline & SAT 4 & 0.875 & & & \\
\hline & SAT 5 & 0.822 & & & \\
\hline \multirow{5}{*}{$\begin{array}{l}\text { Customer } \\
\text { Loyalty }\end{array}$} & LOY 1 & 0.491 & \multirow{5}{*}{0.881} & \multirow{5}{*}{0.830} & \multirow{5}{*}{0.605} \\
\hline & LOY 2 & 0.855 & & & \\
\hline & LOY 3 & 0.847 & & & \\
\hline & LOY 4 & 0.835 & & & \\
\hline & LOY 5 & 0.799 & & & \\
\hline
\end{tabular}

(Source: Survey data)

Further, Hair et al. (1998) stated that discriminant validity assesses the extent to which a measure does not correlate with other constructs from which it is supposed to differ. For adequate discriminant validity, the diagonal values should be significantly larger than the correlation of a specific construct with any other constructs (Hair et al., 2011; Fornell and Larcker, 1981). Table 5 shows that all the diagonal values are larger than the correlation of a specific construct with any other constructs.

Table 5: Discriminant validity

\begin{tabular}{|l|c|l|c|}
\hline Constructs & $\begin{array}{l}\text { Service } \\
\text { quality }\end{array}$ & $\begin{array}{l}\text { Customer } \\
\text { satisfaction }\end{array}$ & $\begin{array}{l}\text { Customer } \\
\text { loyalty }\end{array}$ \\
\hline Service quality & $\mathbf{0 . 8 2 2}$ & & \\
\hline Customer satisfaction & 0.766 & $\mathbf{0 . 8 3 6}$ & \\
\hline Customer loyalty & 0.658 & 0.743 & $\mathbf{0 . 7 7 8}$ \\
\hline
\end{tabular}

(Source: Survey data)

Moreover, Hair et al. (2011) emphasised that loadings of indicators should be higher than their cross loading. Table 6 shows the cross loadings of the indicators with their constructs. As expected, all the indicators had high loading with its predestined construct. Thus, the discriminant validity is confirmed and is sufficient to support the model of this study. 
Table 6: Cross loadings and Cross validated redundancy

\begin{tabular}{|l|c|c|c|c|}
\hline \multicolumn{1}{|c|}{ Indicators } & $\begin{array}{c}\text { Customer } \\
\text { loyalty }\end{array}$ & $\begin{array}{c}\text { Customer } \\
\text { satisfaction }\end{array}$ & $\begin{array}{c}\text { Service } \\
\text { quality }\end{array}$ & $\mathbf{Q}^{2}$ \\
\hline $\begin{array}{l}\text { Service Quality } \\
\text { Tangibles }\end{array}$ & 0.439 & 0.494 & $\mathbf{0 . 6 8 3}$ & \\
\hline Reliability & 0.558 & 0.656 & $\mathbf{0 . 8 6 8}$ & \\
\hline Responsiveness & 0.567 & 0.674 & $\mathbf{0 . 8 8 0}$ & \\
\hline Assurance & 0.571 & 0.687 & $\mathbf{0 . 8 7 6}$ & \\
\hline Empathy & 0.599 & 0.621 & $\mathbf{0 . 7 8 8}$ & \\
\hline $\begin{array}{l}\text { Customer } \\
\text { Satisfaction }\end{array}$ Sat1 & & & & $\mathbf{0 . 4 0 2}$ \\
\hline Sat2 & 0.586 & $\mathbf{0 . 7 9 2}$ & 0.680 & 0.451 \\
\hline Sat3 & 0.584 & $\mathbf{0 . 8 3 2}$ & 0.603 & 0.361 \\
\hline Sat4 & 0.605 & $\mathbf{0 . 8 5 7}$ & 0.622 & 0.381 \\
\hline Sat5 & 0.663 & $\mathbf{0 . 8 7 5}$ & 0.604 & 0.357 \\
\hline Customer Loyalty & 0.659 & $\mathbf{0 . 8 2 2}$ & 0.686 & 0.461 \\
Loy1 & & & & $\mathbf{0 . 3 3 5}$ \\
\hline Loy2 & $\mathbf{0 . 4 9 1}$ & 0.268 & 0.259 & 0.064 \\
\hline Loy3 & $\mathbf{0 . 8 5 5}$ & 0.669 & 0.567 & 0.450 \\
\hline Loy4 & $\mathbf{0 . 8 4 7}$ & 0.591 & 0.523 & 0.353 \\
\hline Loy5 & $\mathbf{0 . 8 3 5}$ & 0.648 & 0.611 & 0.443 \\
\hline
\end{tabular}

(Source: Survey data)

\section{Structural model analysis}

The structural model was used to determine the model's explanatory power and to test the developed hypotheses based on the cause-effect relationship among the constructs. The model's explanatory power was assessed by the coefficient of determination, $\mathrm{R}^{2}$. The coefficient of determination $\left(\mathrm{R}^{2}\right)$ is 0.571 for the "customer loyalty" construct (see figure 2). This means that the two constructs (service quality and customer satisfaction) moderately explain $57.1 \%$ of the variance in customer loyalty since the $\mathrm{R}^{2}>0.50$ (Hair et al., 2011). Further, the coefficient of determination $\left(\mathrm{R}^{2}\right)$ of the "customer satisfaction" construct is 0.587 which means that, the construct of service quality alone moderately explains $58.7 \%$ of the variance in customer satisfaction. 


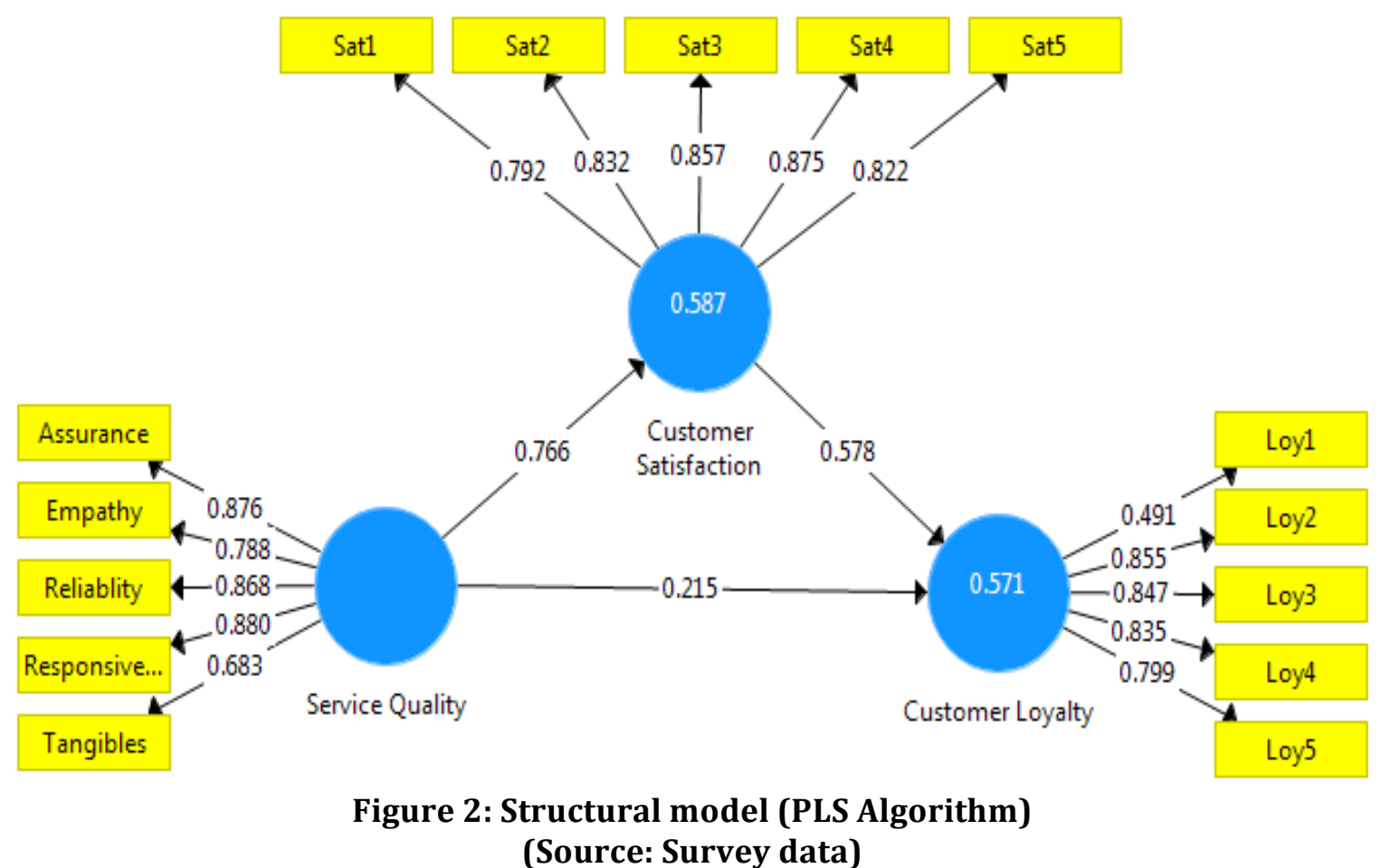

Another important assessment of a structural model is the models' capability to predict. Predictive relevance postulates that the model must be able to adequately predict each endogenous latent construct's indicators (Hair et al., 2011). The $Q^{2}$ value was obtained using the blindfolding procedure with omission distance seven. The $\mathrm{Q}^{2}$ of cross validated redundancy was selected since it uses the PLS-SEM estimates of both the structural model and the measurement models for data prediction. Table 6 shows the $\mathrm{Q}^{2}$ values of constructs and indicators of endogenous latent construct (dependent variables). As all the values were larger than zero, the model adequately predicts each indicator of the endogenous latent constructs.

The strength of the cause- effect relationships were assessed through the path coefficient values $(\beta)$ and bootstrapping has been used to test the significance of structural paths using TStatistics (Hair et al., 2011; Wong, 2013). The inner model suggests that service quality has the strongest effect on customer satisfaction (0.766), followed by customer loyalty (0.215) and customer satisfaction has the strongest effect on customer loyalty $(0.578)$. Thus it is concluded that all the hypothesized path relationships between the constructs; service quality and customer satisfaction; customer satisfaction and customer loyalty; and service quality and customer loyalty were statistically significant.

\section{Hypotheses testing}

As shown in Table 7, the hypotheses were tested using the path coefficient $(\beta)$ indicating the strength of the cause-effect relationship between the research constructs using the $p$ value. The bootstrapping procedure was used to assess the significance of path coefficient values $(\beta)$. The statistical significance was tested at $5 \%(p<0.05)$. 
Table 7: Research hypotheses testing

\begin{tabular}{|l|c|c|c|}
\hline \multicolumn{1}{|c|}{ Hypotheses } & $\begin{array}{c}\text { Path } \\
\text { coefficient } \\
(\beta)\end{array}$ & $\begin{array}{c}\boldsymbol{P} \\
\text { values }\end{array}$ & $\begin{array}{c}\text { Supported/ } \\
\text { Not } \\
\text { Supported }\end{array}$ \\
\hline $\begin{array}{l}\text { Hypothesis 1: Service quality } \rightarrow \text { Customer } \\
\text { satisfaction }\end{array}$ & 0.766 & 0.000 & Supported \\
\hline $\begin{array}{l}\text { Hypothesis 2: Customer satisfaction } \rightarrow \\
\text { Customer loyalty }\end{array}$ & 0.578 & 0.000 & Supported \\
\hline $\begin{array}{l}\text { Hypothesis 3: Service quality } \rightarrow \text { Customer } \\
\text { loyalty }\end{array}$ & 0.215 & 0.040 & Supported \\
\hline $\begin{array}{l}\text { Hypothesis 4: Service quality } \rightarrow \text { Customer } \\
\text { satisfaction } \rightarrow \text { Customer loyalty }\end{array}$ & 0.443 & 0.000 & Supported \\
\hline
\end{tabular}

(Source: Survey data)

\section{Testing Hypothesis 1:}

$\mathbf{H}_{\mathrm{A} 1}$ : There is a direct and positive relationship between service quality and customer satisfaction

According to the results in Table 7 , service quality affected customer satisfaction $(\mathrm{p}=0.00)$ with a larger effect size $(\beta=0.766)$. Since service quality was directly, positively and significantly related to satisfaction of the customers $(\beta=0.766, p<0.05)$, supporting $\mathrm{H}_{\mathrm{A} 1}$. This provides the support to the contention that high service quality of the bank is likely to increase customer satisfaction. The current study finding is supported by a few previous studied on testing these two constructs.

Service quality was identified as a major predictor of customer satisfaction by Santouridis and Trivellas (2010). Overall service quality appears to be a significant determinant of customer satisfaction (Yavas et al., 1997). Sureshchandar et al. (2002) assured that, people who perceive the service quality as high are highly satisfied with the services of the bank. Even in the retail store setting, the influence of service quality on customer satisfaction was proved by Sivadas and Baker-Prewitt (2000). A strong positive individual linear correlation between each service quality dimensions with customer satisfaction was found by Ushantha, Wijeratne and Samantha (2014) in state sector banks in Sri Lanka.

According to Gupta and Dev (2012), improvement in the service quality in the banking industry increases customer satisfaction. Moreover, the positive relationship between service quality and customer satisfaction was confirmed in the Iranian Islamic banking context too (Estiri et al., 2011). A satisfied customer requires a sense of belongingness, individual attention, understanding his/ her needs and having his/ her best interest at heart (Kumar et al., 2009). Consistent examination of the level of customer satisfaction will provide insights to the banks as to what are the areas that need to be improved or maintained that will lead to the development of strategies such as training and retraining their employees and motivating them to become more customer oriented through customer relationship management (Kumar et al., 2009). Further, Tam (2012) suggested that to resolve their problems or to meet their unmet needs, customers seek professional judgement and the skills of the service provider. Further, Attitudes and behaviour of the service provider have strong influence on customer feelings especially to the services which require a high degree of contact with a service provider while the effects of physical environment on customer satisfaction differs depending on the service context. 
Hence it was concluded that, it is $95 \%$ confident that there is a direct and positive relationship between service quality and customer satisfaction in commercial banks of the Northern Province of Sri Lanka.

\section{Testing Hypothesis 2:}

\section{$\mathrm{H}_{\mathrm{A} 2}$ : There is a direct and positive relationship between customer satisfaction and customer loyalty}

As shown in Table 7 , customer satisfaction affected customer loyalty $(p=0.00)$ with an effect size $(\beta=0.578)$ since customer satisfaction was directly, positively and significantly related to customer loyalty $(\beta=0.578, \mathrm{p}<0.00)$, supporting $\mathrm{H}_{\mathrm{A} 2}$. This indicates that customer satisfaction is likely to display higher customer loyalty towards the bank.

The past literature has enough support for the current findings. According to Annamalah et al. (2011), loyalty of the banking customer is directly affected by satisfaction. Satisfied customers ultimately become loyal to the bank (Hassan et al., 2013). Tam (2012) emphasised that the higher the satisfaction the stronger the loyalty towards the firm. Further, it is necessary to a service provider to find the most contributing service aspect of customer satisfaction to loyalty that will help to effectively influence loyalty. Mokhtar et al. (2011) found that customer satisfaction plays an important role to enhance the level of customer loyalty. In other words, the higher the level of satisfaction the more the customer becomes loyal. Further, ensuring customer satisfaction is very important and could be achieved by identifying focusing and improving the factors that determine the level of satisfaction of the clients. Customer satisfaction was found to have a strong effect on customer loyalty (Keisidou et al., 2013) which means that continuous satisfaction with the banking service will make the customer to maintain the transactions continuously with the bank. Since customer satisfaction is the strongest predictor of customer loyalty, the mangers should give their first priority to customer satisfaction where they should listen to the requirements of the customers and create products and services that fulfil the requirement. Furthermore, customer satisfaction has a positive significant impact on customer loyalty in the technology based banking service (Ganguli and Roy, 2011) which means if a customer is once satisfied with the previous encounter he will reuse the same for future transactions especially in the technology based banking service.

Hence it was concluded that there is a direct and positive relationship between customer satisfaction and customer loyalty in the commercial banks of Northern Province of Sri Lanka.

\section{Testing Hypothesis 3:}

\section{$H_{A 3:}$ There is a direct and positive relationship between service quality and customer} loyalty

As shown in Table 7, service quality affected customer loyalty $(p=0.040)$ with an effect size of $\beta=0.215$. Service quality was directly, positively and significantly related to customer loyalty $(\beta=0.215, p<0.05)$, supporting $\mathrm{H}_{\mathrm{A} 3}$. This indicates that the more favourable is the service quality perception of customers, the more loyal they are to their bank.

The current finding coincided with the findings of the scholars. Service quality identified as a major predictor of customer loyalty (Santouridis and Trivellas, 2010). Consumers who perceive the service quality favourably will tend to develop loyalty to the store which will lead to loyalty towards the brand as a consequence (Gurbuz, 2008). Service quality indeed is an important driver of customer retention which was explained by the highest variation in customer retention (Ranaweera and Neely, 2003). If the technology provided is easy to use and reliable as well as convenient, the customers become loyal to the bank especially in the 
technology based banking services (Ganguli and Roy, 2011). Moreover, Zeithaml et al. (1996) also stated that service quality is associated positively with favourable behavioural intentions and negatively with unfavourable behavioural intentions. Further, Sivadas and Baker-Prewitt (2000) argued that recommending a department store to friends was influenced by service quality.

According to Ehigie (2006), due to the intangibility of bank products, service quality is usually assessed by the customer - service provider relationship. Therefore, the banks which are more vigilant on the staffs' skill possession, knowledge, the attention given to customers and their needs, efficient and quick service deliveries, and the general attitude to customer service will achieve more. Further, in Nigerian banking context, confidentiality in transactions, trustworthiness of banks, introduction of weekend banking, extension of banking hours and provision of insurance for customers were identified as the important issues in gaining customer loyalty. Moreover, Malik et al. (2011) postulated that service quality dimensions have a positive impact on customer loyalty in the Pakistani context. Further, a study of Sri Lankan Telecom PLC (Karunanithy and Rasanayagam, 2013) also found a higher positive relationship between service quality and customer loyalty where they stated that there is a high chance to improve customer loyalty by improving the service quality.

Hence, it was concluded that in commercial banks of Northern Province of Sri Lanka too there is a positive relationship between service quality and customer loyalty.

\section{Testing Hypothesis 4:}

\section{$H_{A 4:}$ There is an indirect and relationship between service quality and customer loyalty through customer satisfaction}

More interestingly the findings revealed that service quality and customer loyalty were mediated by customer satisfaction. Thus the total effect showed that service quality affected customer loyalty $(p=0.00)$ with an effect size $(\beta=0.658)$ totally (see table 8$)$.

Service quality affected customer loyalty through customer satisfaction $(\mathrm{p}=0.00)$ with an effect size of $\beta=0.443$ (see table 7 and 8 ). This revealed an indirect relationship between the constructs service quality and customer loyalty through customer satisfaction $(\beta=0.443, p<$ 0.05). Evidence from the past researches of several scholars supported this finding (Hassan et al., 2013; Annamalah et al., 2011; Santouridis and Trivellas, 2010; Caruana, 2002). According to Annamalah et al. (2011), satisfaction mediates the relationship between service quality and customer loyalty which showed that, customer loyalty can be achieved through improving customer satisfaction where customer satisfaction is determined by customer perceptions of service quality. Hassan et al. (2013) highlighted that high quality service will eventually turn satisfied customers into loyal customers. This requires the managers to pay full attention to how the service is being offered by the bank in order to make the customers satisfied and build long term relationships with the bank. Dhandabani (2010) identified service quality as an important driver of customer loyalty and that its indirect effect through customer satisfaction was larger than the direct effect in the generation of customer loyalty. Further, Caruana (2002) provided support for a completely mediated effect of service quality on customer loyalty via customer satisfaction while the direct link between service quality and customer loyalty was insignificant.

Therefore, it is obvious that there is an indirect positive and significant relationship between service quality and customer loyalty through customer satisfaction. 
Table 8: Direct, indirect and total effect between constructs

\begin{tabular}{|c|c|c|c|c|c|c|}
\hline \multirow{2}{*}{ Path } & \multicolumn{2}{|c|}{ Direct effect } & \multicolumn{2}{c|}{ Indirect effect } & \multicolumn{2}{c|}{ Total effect } \\
\cline { 2 - 7 } & $\begin{array}{c}\text { Path } \\
\text { coefficient }\end{array}$ & $\begin{array}{c}\text { P } \\
\text { value }\end{array}$ & $\begin{array}{c}\text { Path } \\
\text { coefficient }\end{array}$ & $\begin{array}{c}\text { P } \\
\text { value }\end{array}$ & $\begin{array}{c}\text { Path } \\
\text { coefficient }\end{array}$ & $\begin{array}{c}\text { P } \\
\text { value }\end{array}$ \\
\hline $\begin{array}{c}\text { Service quality } \rightarrow \begin{array}{c}\text { Customer } \\
\text { satisfaction }\end{array} \\
0.766\end{array}$ & 0.000 & - & - & 0.766 & 0.000 \\
\hline $\begin{array}{c}\text { Customer satisfaction } \rightarrow \\
\text { Customer loyalty }\end{array}$ & 0.578 & 0.000 & - & - & 0.578 & 0.000 \\
\hline $\begin{array}{c}\text { Service quality } \rightarrow \text { Customer } \\
\text { loyalty }\end{array}$ & 0.215 & 0.040 & 0.443 & 0.000 & 0.658 & 0.000 \\
\hline
\end{tabular}

(Source: Survey data)

\section{CONCLUSION}

According to the findings, customer loyalty is moderately explained by both service quality and customer satisfaction and service quality alone moderately explained the customer satisfaction in the Commercial banks of Sri Lanka. It revealed that there were significant positive relationships between service quality and customer satisfaction, customer satisfaction and customer loyalty and service quality and customer loyalty. Further, it is observed that the relationship between service quality and customer loyalty mediated by customer satisfaction. Therefore, it was concluded that higher levels of service quality of banks lead to higher levels of customer satisfaction, and customer loyalty. Further, it was concluded that customer loyalty towards the banks can be enhanced through higher levels of customer satisfaction. It also revealed that improving the service quality of the banks directly leads to enhancing customer satisfaction which eventually leads to enhance customer loyalty towards the banks. Hence, not only customer satisfaction but also service quality can be recognized as critical factor to which banks should pay more attention.

\section{IMPLICATIONS OF THE STUDY}

The findings of the current study provided the following implications for both theory and practice.

\section{Theoretical implications}

The current study revealed the applicability of the SERVQUAL model of 22 items of Parasuraman et al. (1988) to the Sri Lankan context. This study confirmed the fivefold service quality dimensions namely, tangibles, reliability, responsiveness, assurance and empathy in the commercial banking sector in the Sri Lankan context, proving service quality as a multidimensional construct as mentioned in the literature. The current study narrowed the empirical gap by exploring the role of service quality on customer satisfaction and customer loyalty. The findings showed that the banks with a higher level of service quality can develop higher levels of customer satisfaction, and customer loyalty. Further the study revealed that customer loyalty is highly impacted by customer satisfaction, for which service quality is identified as an important predictor. Moreover, the mediation of customer satisfaction between service quality and customer loyalty also proved in the Commercial banks of Sri Lanka.

\section{Practical implications}

Since the offerings of the banks are more or less similar in the competitive banking industry, one bank can differentiate itself from another only through the quality of the service they deliver. Developing higher levels of service quality in the banks leads to enhance customer satisfaction and customer loyalty. As loyal customers are the profitable customers, banks are searching ways to make their customers loyal to them. Customer loyalty towards the banks 
could be achieved by enhancing customer satisfaction and service quality of banks also indirectly affects customer loyalty through customer satisfaction. Developing proper strategies to improve the service quality in all the aspects; maintain the same level of quality in every points of contact; having right employees who really care for customers and an attractive and conducive physical environment will leads to feel the higher level of service quality which consequently satisfy the customers and that eventually leads to make the customers loyal to the bank.

\section{LIMITATIONS OF THE STUDY}

Even though the current study carries important implications and new insights to commercial banks, to academics and especially to managers in the banking industry, there were a few inherent limitations identified in this study.

a) Mainly service quality and customer satisfaction were considered as important determinants of the study. Apart from these constructs, other constructs which influence customer loyalty namely; value, trust, corporate image and commitment also could be studied to predict customer loyalty.

b) The current study explored the relationships between three constructs only in the commercial banks of the Northern Province of Sri Lanka.

c) Only four banks were selected including two state banks and two private banks and therefore care should be taken in generalizing the findings. The sample was selected using the convenience sampling method among the selected banks and the sample size was limited to three hundred.

d) The reliability of data depended on the respondents' understanding and perceptions as given in the self-reported data.

\section{FUTURE RESEARCH DIRECTION}

Even though the current study narrowed the empirical gap, it still provides a pathway for future research. First, the objective of the current study was to explore the influence of service quality and customer satisfaction on customer loyalty in commercial banks of the Northern Province of Sri Lanka, therefore it did not include banks other than commercial banks in the banking industry. It also focused on the Northern Province of Sri Lanka. Thus the scope of generalizing the results to other contexts and to the whole of Sri Lanka may be limited. Therefore, covering the whole banking industry in all of Sri Lanka may provide new findings. Further, replications in other service contexts are highly desirable. Comparison of models of government and private banks will give more understanding on the difference between them. Further, developing a richer model that incorporates other constructs such as value, trust and corporate image will also give further insights.

\section{References}

Akhter, W., Abbasi, A.S., Ali, I. and Afzal, H. (2011), Factors affecting customer loyalty in Pakistan, African Journal of Business Management, Vol.5 No. 4, pp.1167-1174

Andreassen, and Lindestad, B. (1998), Customer Loyalty and complex services: The impact of corporate image on quality, customer satisfaction and loyalty for customers with varying degree of service expertise, International Journal of service industry management. Vol.9 No. 1, pp. 7- 23

Annamalah, S., Munusamy, J., Chelliah, S., Sulaiman, M. and Pandian, S. (2011), Service Quality Transformation and its Impact on Customer Satisfaction and Loyalty in Malaysian Retail Banking Sector, World Applied Sciences Journal. vol.15 No.10, pp. 1361-1368

Arasli, H., Katircioglu, S.T. and Mahtap-Smadi, S. (2005), A comparison of service quality in the banking industry: 
some evidence from Turkish and Greek speaking areas in Cyprus, International journal of bank marketing. Vol.23 No.7, pp. 508-526 119

Bloemer, J., Ruyter, K.D. and Peeters, P. (1998), Investigating drivers of bank loyalty: the complex relationship between image, service quality and satisfaction, International Journal of Bank Marketing. vol. 16/7, pp.276-286.

Bloemer, J., Ruyter, K.D. and Wetzels, M. (1999), Linking perceived service quality and service loyalty: a multidimensional perspective, European journal of marketing, Vol.33 No.11/12, pp. 1082-1106

Caruana, A. (2002), Service loyalty: The effects of service quality and the mediating role of customer satisfaction, European Journal of Marketing, 36(7/8), 811-828.

Dean, A.M (2002), Service quality in call centres: Implication for customer loyalty. Managing service quality, Vol. 12 No. 6, pp. 414- 423

Dhandabani,S. (2010), Linkage between service quality and customer loyalty in commercial banks, International Journal of Mannagement and strategy. Vol. 1 No.1, pp. 1-22

Dick, A.S. and Basu, K. (1994), Customer Loyalty: Toward an integrated conceptual framework, Journal ofacademy of marketing science. Vol. 22, No.2, pp.99-113

Ehigie, B.O. (2006). Correlates of customer loyalty to their bank: a case study in Nigeria, International Journal of Bank marketing. Vol. 24 No.7, pp.494-508

Estiri, M., Hosseini, F., Yazdani, H. and Nejad, H.J. (2011), Determinants of customer satisfaction in Islamic banking: evidence from Iran, International Journal of Islamic and Middle Eastern Finance and Management. Vol.4 No.4, pp. 295-307.

Fatima, J.K. and Razzaque, M.A. (2014), Service quality and satisfaction in the banking sector, International Journal of Quality and Reliability Management. Vol. 31, No. 4, pp. 367-379.

Filip, A. and Anghel, L.D. (2009), customer loyalty and its determinants in a banking services environment, Amfiteatru Economic, Vol.11 No.26, pp.288-297.

Fornell, C. and Larcker, D. (1981), Evaluating structural equation models with unobservable variables and measurement error, Journal of Marketing Research, vol.18 No.1, pp.39-50 122

Ganguli, S. and Roy, S.K. (2011), Generic technology based service quality dimensions in banking: impact on customer satisfaction and loyalty, International journal of bank marketing. Vol.29 No.2, pp. 168- 189

Giese, J. and Cote, J. (2000), Defining customer satisfaction, Academy of marketing Science Review, Vol.2000 No.1 Available: http://www.amsreview.org/articles/giese01-2000.pdf

Gremler, D.D. and Brown, S.W. (1996), Service loyalty: Its nature, importance, and implications, In: B. Edvardsson, S.W. Brown and R.E. Johnston, Editors, Advancing service quality: a global perspective, International Service Quality, pp. 171-180

Gremler, D.D. and Gwinner, K.P. (2000). Customer-Employee Rapport in Service Relationships. Journal of Service Research, Volume 3, No. 1, pp. 82-104

Gronroos, C. (1984). A Service Quality Model and its Marketing Implications. European Journal of Marketing, Vol. 18 No. 4, pp.36-44

Gupta, A.and Dav, S. (2012), Client satisfaction in Indian banks: an empirical study, Management Research Review, Vol.35 No.7, pp. 617-636.

Gurbuz, E. (2008), Retail store branding in Turkey: its effect on perceived service quality, satisfaction and loyalty, EuroMed Journal of Business. Vol. 3 No.3, pp.286- 304

Hafeez, S. and Muhammad, B. (2012), The Impact of Service Quality, Customer Satisfaction and Loyalty Programs on Customer's Loyalty: Evidence from Banking Sector of Pakistan, International Journal of Business and Social Science. Vol.3 No.16, pp. 200- 209.

Hair, J.F. Ringle, C.M. and Sarstedt, M. (2011), PLS-SEM: Indeed a silver bullet, Journal of Marketing Theory and Practice, Vol.19 No.2, pp.139-151

Hair, J.F., Anderson, R.E., Tatham, R.L. and Black, W.C. (1998), Multivariate Data Analysis, 5th ed., Prentice Hall, Englewood Cliffs, NJ.

Hallowell, R. (1996), The relationships of customer satisfaction, customer loyalty and profitability; an empirical study, International journal of service industry management. Vol.7 No.4, pp.27- 42 
Hassan, M.U., Mallik. A.A., Imran, M. Hasnain, A. and Abbas, J. (2013), Relationship among customers' perceived service quality, satisfaction and loyalty in the retail banking sector of Pakistan, World applied sciences Journal. Vol. 24 No. 8, pp.1020-1030.

Jamal, A., and Naser, K. (2003). Factors influencing customer satisfaction in the retail banking sector in Pakistan. International Journal of Commerce and Management, Vol. 13 No.2, pp.29-53

Kandampully, J. (1998), Service quality to service loyalty: A relationship which goes beyond customer services, Total Quality management, Vol. 9, No.9.pp. 431-443.

Karunanithy, K. and Rasanayagam, D. (2013), Impact of customer satisfaction on customer loyalty towards Sri Lankan Telecom PLC, Industrial Engineering letters, Vol.3 No.7, pp. 66-71

Kaura, V. (2013), Antecedents of customer satisfaction: A study of Indian public and private sector banks, Vol.31 No.3, pp.167-186.

Keisidou, E., Sarigiannidis, L., Maditinos, D.I., and Thalassinos, E.I. (2013), Customer satisfaction, loyalty and financial performance: A holistic approach of the greek banking sector, International Journal of Bank Marketing, vol.31 No.4 pp.259-288

Kheng, L. L., Mahamad, O., Ramayah, T. and Mosahab, R. (2010), The Impact of Service Quality on Customer Loyalty: A Study of Banks in Penang, Malaysia, Vol. 2, No. 2, pp.57-66.

Kiran, K. and Diljit,S. (2011), Antecedents of customer loyalty; does service quality suffice?, Malaysian journal of Library and Information science, Vol.16. No.2, pp. 95-113

Komunda, M. and Osarenkhoe, A. (2012), Remedy or cure for service failure?: Effect of service recovery on customer satisfaction and loyalty, Business Management Process journal. Vol.18, No.1, pp- 82-103 125

Kotler, P. (2003). Marketing Management. 11 th Edi, Prentice Hall, pp.36

Kumar, M., Kee, F. T., and Manshor, A. T. (2009), Determining the relative importance of critical factors in delivering service quality of banks: an application of dominance analysis in SERVQUAL model, Managing Service Quality, 19(2), 211-228.

Kumaradeepan, V. (2012). The impact of service quality on customer swicthing in telecommunication industry Jaffna, Sri Lanka. ZENITH International Journal of Business Economics and Management Research, Vol.2 No.5, pp. $222-231$

Lee, S.C., Barker, S. and Kadampully, J. (2003), Technology, service quality and customer loyalty in hotels: Australian Managerial perspectives, Managing service quality, Vol. 13 No. 5, pp. 423- 432126

Malik, M.E., Naeem, B. and Arif, Z. (2011), Impact of perceived service quality on Banking customers' loyalty, Interdisciplinary Journal of contemporary research in Business, Vol.3 No.8, pp.637-645

Mosahab, R., Mahamad, O. and Ramyah, T. (2010), Service quality, customer satisfaction and loyalty; A test of mediation, International Business Journal, Vol.3 No.4, pp. 72- 80.

Oliver, R. (1997), Satisfaction: A behavioural perspective on the consumer, McGraw-Hill,New York

Oliver, R.L. (1980), A cognitive model of the antecedents and consequences of satisfaction decisions, Journal of Marketing Research, Vol. 17, No.4, pp. 460-469. 127

Oliver, R.L. (1993), A conceptual model of service quality and service satisfaction: compatible goals, different concepts, in Swartz, T.A., Bowen, D.E. and Brown, S.W. (Eds), Advances in Services Marketing and Management, Vol. 2, JAI Press, Greenwich, CT, pp. 65-85.

Olorunniwo, F. and Hsu,M.K. (2006), A typology analysis of service quality, customer satisfaction and behavioural intention in mass services, Managing service quality, Vol.16 No.2, pp.106-123

Ou, W.M., Shih,C.M., Chen, C.Y. and Wang, K.C. (2011), Relationships among customer loyalty programs, service quality, relationship quality and loyalty: An empirical study, Chinese management Studies, Vol.5 No. 2, pp, 194206

Parasuraman, A., Berry, L. L., and Zeithaml, V. A. (1988), SERVQUAL: A multiple-item scale for measuring consumer perceptions of service quality, Journal of Retailing, 64(1), 12.

Parasuraman, A., Zeithaml, V. and Berry, L.L. (1985), A conceptual model of service quality and its implications for future research, Journal of Marketing, Vol. 49, Autumn, pp. 41-50.

Peng, L. Y. and Wang, Q. (2006), Impact of Relationship Marketing Tactics (RMTs) on Switchers and Stayers in a 
Competitive Service Industry, Journal of Marketing Management, Vol.22, pp.25-59.

Poku,K., Zakari, M. and Soali, A. (2013), Impact of Service Quality on Customer Loyalty in the Hotel Industry: An Empirical Study from Ghana, International Review of Management and Business Research. Vol.2 No.2, pp. 600609.

Prentice, C. (2013), Service quality perceptions and customer loyalty in casinos, International Journal of Contemporary Hospitality Management. Vol.25 No. 1, pp.49-64.

Puja, K. and Yukti, A. (2011), Relationship between service quality and brand loyalty in restaurants; a cross cultural study, International Journal of Engineering and Management Sciences, Vol. 2 No.4, pp, 205-215

Rahman, M.A. and Kamarulzaman, Y. (2012), The influence of relationship quality and switching costs on customer loyalty in the Malaysian Hotel industry, Procedia-Social and behavioural sciences. Vol.62, pp. 10231027.

Ranaweera, C. and Neely, A. (2003), Some moderating effects on the service quality- customer retention link, Vol.23 No.2, pp.230-248

Ranganathan, S.K., Madupu, V., Sen, S., and Brooks, J.R. (2013), Affective and Cognitive antecedents of customer loyalty towards e-mail service providers, Journal of Services Marketing, 27/3, pp. 195- 206

Roostika, R. (2011), The effect of perceived service quality and trust on loyalty: customer's perspectives on mobile internet adoption, International Journal of Innovation, Management and Technology. Vol.2 No.4, pp. 286-291

Ruyter, K.D., Wetzels, M. and Bloemer, J. (1998), On the relationship between perceived service quality, service loyalty and switching costs, International journal of service industry management, Vol. 9 No. 5, pp. $436-453$

Santouridis and Trivellas, P. (2010), Investigating the impact of service quality and customer satisfaction on customer loyalty in mobile telephony in Greece, The TQM Journa, Vol.22 No.3, pp.330-343

Siddiqi, K.O. (2011), Interrelationship between service quality attributes, customer satisfaction and customer loyalty in the retail banking sector in Bangladesh, International Journal of Business and Management, Vol.6 No.3, pp. 12-36.

Silva, V. (2009), Unleash potential through effective service quality determinants, 21st Anniversary Convention.

Sivadas, E., and Baker-Prewitt, J.L. (2000), An examination of the relationship between service quality, customer satisfaction and store loyalty, International journal of retail and distribution management, Vol.28 Iss: 2 pp.73-82

Sivesan, S. (2012), service quality and customer satisfaction: a case study - banking sectors in Jaffna district, Sri Lanka, International Journal of Marketing, Financial Services \& Management Research, Vol.1 No. 10, pp. 1-9

Suh, J.C. and Yi, Y. (2006), When brand attitudes affect the customer satisfaction- loyalty relation: The moderating role of product involvement, Journal of Consumer Psychology, Vol. 16 (2), pp.145-155

Sureshchandar, G., Rajendran, C. and Anantharaman, R. (2002), The relationship between service quality and consumer satisfaction - a factor specific approach, Journal of Services Marketing, Vol. 16 No. 4, pp. 363-79.

Tam, J.K.M. (2012), The moderating role of perceived risk in loyalty intentions: an investigation in a service context, Vol. 30 No.1, pp.33-52.

Tarus, D.K., and Rabach, N. (2013), Determinants of customer loyalty in Kenya: does corporate image play a moderating role?, The TQM Journal, vol.25 No.5 pp. 473- 491

Ushantha, R.A.C., Wijeratne, A. W., \& Samantha, P. A. P. (2014). Customers' Perception on Service Quality towards Satisfaction: An Application of SERVPERF in State Sector Banks in Sri Lanka. European Journal of Business and Management, Vol. 6 No.4, pp.72-81

Wong, K.K. (2013), Partial Least Squares Structural Equation Modeling (PLS-SEM) Techniques Using SmartPLS, Marketing Bulletin, 2013, 24, Technical Note 1, pp.1-32 (http://marketing-bulletin.massey.ac.nz)

Yang, Z. and Peterson,R.T. (2004), Customer perceived value, satisfaction and loyalty: the role of switching costs, Journal of Psychology and Marketing, Vol.21 No.10, pp.799-822

Yavas, U., Bilgin, Z. and Shemwell, D.J. (1997), Service quality in the banking sector in an emerging economy: a consumer survey, International Journal of Bank Marketing, Vol. 15 (6), pp. 217-223.

Yi, Y. (1990). “A critical review of consumer satisfaction”, in Zeithaml, V. (Ed.): Review of Marketing, American Marketing Association, Chicago, IL, 68-123. 
Zeithaml, V.A. (1981), How Consumer Evaluation Processes Differ Between Goods and Services, Marketing of Services, J. H. Donnelly and W. R. George, eds. Chicago, IL: American Marketing Association, 186-190.

Zeithaml, V.A., Berry, L.L., and Parasuraman, A. (1996), The behavioural consequences of service quality. Journal of Marketing, pp. 31-46.

Zeithaml, V.A., Bitner, M.J., Gremler, D.D. and Pandit.A. (2011), Services Marketing, 5th Edi, Tata McGraw hill Education Pvt Ltd, New Delhi. 